Németh Imre

\title{
A KÖZERKÖLCS BÜNTETŐJOGI VÉDELMÉNEK INDOKOLTSÁGA ÉS TÖRTÉNELMI ELŐKÉPEI A KBTK. RENDSZERÉBEN
}

Arguments and Historical Antitypes of Criminal Law Protection of Public Morality in the System of the Criminal Code of Tresspasses

Dr. Németh Imre LL.M. (Helsinki), PhD (SZE), egyetemi adjunktus, Eötvös Loránd Tudományegyetem Állam- és Jogtudományi Kar Büntetőjogi Tanszék, nemeth.imre@ajk.elte.hu

A tanulmány háttere a Kbtk. 140. évfordulójára rendezett konferencia. A cikk igyekszik megvilágítani, melyek voltak azok a kihágások, amelyek célja a közerkölcs védelme. Ezt követöen a tanulmány kitér arra is, manapság hogyan befolyásolja a közerkölcsvédelem a kriminalizációt, mindezt nemzetközi szempontból röviden elemzi. A munka jellemzöen jogtörténeti módszert alkalmaz. A szerző megállapitása, hogy a büntetöjogi jogalkotás a Kbtk. megalkotásakor is figyelmet fordított a közerkölcs jogi tárgyának védelmére, sőt módszerében és terjedelmében a szabályozás a mai nemzetközi jogi standardoknak is megfeleltethetö.

KulcsszavaK:

Kbtk., kihágás, közerkölcs védelme, kriminalizáció, nemzetközi jogi standardok

The backgound of the study stems from a conference organised for the $140^{\text {th }}$ anniversary of the first Hungarian Criminal Code on Tresspasses. The article aims to highlight those criminal misdemeanours (tresspasses) which used to cover the protection of public morality, followed by general remarks and thoughts on how public morality influences criminal legislation nowadays in an international context. Thus, the study mainy applies historical method. The article argues, that criminal legislation historically takes account of those minor offences which endangered public morality, nevertheless nowadays' international standards for criminalisation are very much similar to that methodology which one may discover while srutinizing the first Hungarian Criminal Code on Tresspasses.

KeYwORDS:

criminalisation, criminal legislation, misdemeanours, public morality, tresspasses 


\section{BEVEZETÉS}

Jogtörténeti szempontból a Csemegi-kódex érája alatti trichotóm rendszerben az 1879. évi XL. törvénycikk (Kbtk.) kitüntetett szerepet töltött be. Fontos megjegyezni, hogy a Kbtk. hatálybalépésekor a büntetőjogi dogmatika ma ismert alapaxiómái még csak kialakulóban voltak. ${ }^{1}$ Még inkább igaz ez az állítás az alkotmányos büntetőjog kontextusában, azaz a kriminalizáció és dekriminalizáció alkotmányos korlátai és előfeltételei a Kbtk. időszakában még hiányoztak. Ugyancsak nem beszélhetünk ebben az időszakban nemzetközi kriminalizációs kötelezettségekröl, mint ahogyan a nemzetközi emberi jogi standardok sem érvényesültek a belső jogi jogalkotásban. ${ }^{2}$

Elöljáróban a fentieket azért tartom szükségesnek megjegyezni, mert e rövid tanulmányom témájaként a közerkölcsre vonatkozó kihágások vizsgálatát választottam, mert ez az a terület (t.i. a közerkölcs), amely az állam büntetőhatalmának (jus puniendi) a magánszférába történő behatolását a legképletesebben szemlélteti, és lakmuszpapírként mutatja az egyének rendelkezési jogának terjedelmét, az egyén és az állam jogviszonyát. Az erkölcsi minimumelvárások jogba integrálása nemcsak kodifikációs előnyökkel jár, hanem kifejezi a mindenkor érvényes, általánosan elvárható magatartás zsinórmértékét is. Ha a jogrendszerben erkölcsi tételek is megjelennek - persze megfelelően érvényes jogi normában - azzal számolhatunk, hogy az erkölcsi normarendszer megfelelő mintául szolgál majd az állampolgárok számára. ${ }^{3}$

Az erkölcs és a jog összegfüggésének kérdéskörére külön jogfilozófiai irányzat, a jogi moralizmus alakult. Az erkölcs és jog közötti kapcsolat egy szelete, nevezetesen a büntetőjogi erkölcsvédelem legmarkánsabban a Devlin-Hart-vitában domborodott ki. ${ }^{4}$ A jogfilozófiai nézőpontokon túlmenően azonban mára már egyes nemzetközi szerződések is tartalmaznak az erkölcsök védelme érdekében büntetőjogi jogkorlátozást lehetővé tevő passzusokat. $^{5}$

Mindezen hiátusok ellenére érdekes a Kbtk. kodifikációja, az egyes tényállások megfogalmazása a fenti szempontok szerinti, mai kriminalizációs standardoknak egyértelmüen megfeleltethetők. A „közerkölcs” védelmének Kbtk.-ban megjelenő előképei egyúttal pillanatfelvételt nyújtanak az akkori polgári Magyarország büntetőpolitikájáról.

1 A kontinentális büntetőjogi dogmatika a 19. század utolsó harmadának terméke. Ahogyan Pokol fogalmaz: „Csak a tényállásszerűen megfogalmazott bűncselekményekből álló büntetőjog felel meg a nullum crimen sine lege elvnek, az analógia büntetőjogban való használatának szigorú tilalma mellett, és a feszes büntetőjogi dogmatika ezutáni kiépítése az 1800-as évek folyamán ebből nyerte az ösztönzést.” Pokol Béla: Büntetőjogelméleti vizsgálódások. Budapest, Rejtjel, 2016. 58-59.

2 A humanitárius jogi abszolút kriminalizációs kötelezettséget alapvetően az 1949. évi genfi konvencióktól számíthatjuk, amely időpontra a Kbtk. már-már hatályát veszítette.

Németh Imre: Gondolatok az erkölcsi alapú kriminalizációról. Közjogi Szemle, (2011), 3. 28-37. 37.

A vita kirobbantója a beleegyezésen alapuló homoszexuális kapcsolat dekriminalizációjára javaslatot tevő Wolfenden-jelentés volt.

5 Így például az Emberi Jogok Európai Egyezménye 8. cikk (2) bekezdése szerint a magán- és családi élethez való jog korlátozása bizonyos feltételek együttállása esetén a közerkölcs védelme érdekében jogszerűnek minősül. 


\section{KÖZERKÖLCS ÉS BÜNTETÖJOGI JOGKORLÁTOZÁS}

A római jogi mos rendszere áthatotta a „római büntetőjog” alapvonalait is azáltal, hogy mind az iniuriák esetén, mind pedig a közösséggel szembeni cselekedeteknél megjelenik a jó erkölcsökkel szembeni (adversus bonos mores) magatartás. ${ }^{6}$ Az erkölcs és jog viszonyának történetileg első megjelenési formája a római jogi normatív mos (mores) ${ }^{7}$ szabályaiban manifesztálódott, amely a szokások alapján elvárható, illendő magatartás zsinórmértékét támasztotta a polgárokkal szemben.

A büntetőjognak az a feladata, hogy a társadalom által elfogadott alapértékeket védje. Ebből következően a büntetőjognak értékvédő, egyúttal értékteremtő szerepe van. Specialitása, hogy a büntetőpolitika konstans értékekkel tölti meg a büntetőjogot, másrészt viszont az aktuális berendezkedés értékeinek rendszere közvetlenül befolyásolja a büntetöjogi értékvilágot. ${ }^{8}$ Tény, hogy a büntetőpolitika soha nem nélkülözte az erkölcsi normák támasztékát. Az erkölcsi minimumelvárások büntetőjogba építése azon túl, hogy kodifikációs előnyökkel is jár, egyúttal kifejezi az általánosan elvárható magatartás zsinórmértékét is. Ha a jogrendszerben erkölcsi tételek is megjelennek - persze megfelelően érvényes jogi normában -, azzal számolhatunk, hogy az erkölcsi normarendszer megfelelő mintául szolgál az állampolgárok számára.

Az erkölcstelenség kriminalizációjával kapcsolatos jogfilozófiai irányzatok a HartDevlin-vitában csúcsosodtak ki. A konzervatív álláspontot megjelenítő Devlin úgy véli, hogy a büntetőjog mindaddig biztosíthatja a társadalom integritásával összeegyeztethető maximális egyéni szabadságot, amíg az emberi cselekedet el nem éri a tolerancia határát. Ahol az intolerancia kezdődik, ott már nem lehet szerepe az egyéni jogoknak és érdekeknek, mert ott már a társadalom integrációjáról van szó. Az intolerancia kezdőpontja pedig az ahol a közösség, illetve az átlagember valódi undort érez az adott cselekedet iránt. Az intolerancia határai Devlin szemlélete szerint folyamatosan változnak, ezért a jog csak óvatosan teheti magáévá az új igényeket, mert előbb meg kell bizonyosodni, hogy a társadalmi undor elég komoly és általános. Mivel azonban a társadalom által alkotott erkölcsi elvek hálózatának teljességét lehetetlen lenne jogi úton kikényszeríteni, a társadalmat összetartó minimális erkölcsi tartalom jogi kikényszerítése a reális cél, egyben feladat. ${ }^{9}$

6 Molnár Imre: Az ókori római bűncselekmény-fogalom ismérvei. Acta Universitatis Szegediensis. Acta Juridica et Politica, (2010), 73. 565-590. 576.

7 A mosból eredeztetett erkölcs a mores maiorum, azaz „az ősök szokásai” fogalomból származik. Vö. Hamza Gábor - Földi András: A római jog története és institúciói. Budapest, Nemzeti Tankönyvkiadó, 1996. 27.

8 Nagy Ferenc: Régi és új tendenciák a büntetőjogban és a büntetö-jogtudományban. Budapest, Akadémiai Kiadó, 2013. 34 .

9 A társadalmi undorra alapozott kriminalizáció példájaként Devlin az állatkínzást említi, amelyet szerinte kizárólag az erkölcstelenség alapján lehet tiltani, és a társadalmi megvetés az ilyet tevő emberrel szemben olyan mértékű, hogy a jognak be kell avatkoznia az erkölcs ezt tiltó szabályának kikényszerítése végett. Hasonlóképpen, a homoszexualitás büntetendőségét is attól teszi függővé, hogy az átlagember undora bevonja-e a büntetőjogi értékelési körbe az ilyen cselekedetet. Vö. Patrick Devlin: The Enforcement of Morals. Oxford, Oxford University Press, 1965. 17-18. 
Hartnak az erkölcsre tett megállapítása szerint a fennálló, társadalmi pozitív erkölcs kritizálható, tehát létezik valamiféle kritikai erkölcs, ami elvi szinten megalapozható. A kritikai erkölcs része azonban, hogy az emberi szabadság olyan önmagában vett érték, amelynek korlátozása helytelen, illetve csak megfelelő mérlegelés és ellensúly esetén lehetséges. ${ }^{10}$ A Devlin által felvetett „társadalmi undorral” párhuzamba állítva a megbotránkoztatást mint kriminalizációs indokot vizsgálva Hart állítása az, hogy pusztán a cselekmény megbotránkoztató jellegét ilyen indokként kezelni azért veszélyes, mert ezáltal valamennyi erkölcstelenség kriminalizálható volna, amennyiben a megbotránkoztatás bélyegét rásütjük. Gondolatmenete szerint megbotránkoztató csak nyilvános cselekmény lehet, így a magánszféra keretein belül megvalósuló privát erkölcstelenségek a jogi szabályozás körén kívül esnek. Annál is inkább, mivel az ember elismert cselekvési szabadsága is amellett indokol, hogy e privát erkölcstelenségek kapcsán az állam ne korlátozza az egyén cselekvési szabadságát.

A paternalizmus, illetve a jogi moralista felfogás szerint tehát az állam egyes cselekményeket pusztán azon indokból büntetendővé nyilváníthat, hogy az adott cselekmény súlyosan erkölcstelen. A moralista jogi paternalizmus pedig az elkövetőt saját morális sérülésétől kívánja megvédeni a kriminalizáció útján. ${ }^{11}$

George P. Fletcher - annak megállapítása mellett, hogy a jogszabályi rendelkezésekbe ütköző magatartás egyben helytelen is - kiemeli, hogy a jogszabályba ütköző magatartás nem feltétlenül tekinthető erkölcsi értelemben is rossznak. Annak ellenére ugyanis, hogy a legtöbb büncselekménynek morális gyökerei vannak, léteznek olyan tényállások, amelyek jellemzően pusztán preventív tilalmakat állítanak fel. E büncselekményekre jó példa lehet valamely dolog birtoklásának tilalmazása útján történő kriminalizáció, amely tiltás megszegése - annak ellenére, hogy jogellenes - morálisan mégsem tekinthető rossznak. Vannak azonban olyan büncselekmények, amelyek már eleve magukban hordozzák az erkölcsi elítélendőséget, tehát elkövetésük materiális és morális értelemben is helyteleníthetö. ${ }^{12}$

Ahogyan Viski mindezt a társadalomra veszélyesség tudatánál részletesen kifejti: „[A] cselekményekkel kapcsolatban, amelyeknek társadalmi károsságáról az egyén csak a jogszabályokból szerezhet tudomást, és amelyeknél ennélfogva a közösségi motívum csak a jogszabály ismeretén keresztül, közvetve érvényesülhet, még egy lehetőséget kell felvetni. Ez pedig a közösségi motívum érvényesüléséhez elengedhetetlen tudattartalom hiánya. A hiány oka lehet az, hogy az egyén egyáltalán nem szerzett soha tudomást a vonatkozó tiltásról vagy előírásról, de lehet az is, hogy az nála csupán feledésbe merült, vagy egyszerűen nem gondolt arra a cselekmény tudati előkészítése során. Az erkölcsi rosszalás lehetősége abban az esetben hiányzik, ha az egyénnek egyáltalán nem is volt módjában a tudomás megszerzése. Minden más esetben rosszalást érdemel a magatartása,

H. L. A. Hart: Jog, szabadság, erkölcs. Budapest, Osiris Kiadó, 1999. 86.

Joel Feinberg: The Moral Limits of the Criminal Law IV. Harmless Wrongdoing. Oxford - New York, Oxford University Press, 1990. 3-9.

12 George P. Fletcher: Basic Concepts of Criminal Law. Oxford - New York, Oxford University Press, 1998. 77. 
hiszen a társadalmi elvárás nem kis részben éppen arra irányul, hogy a közösség tagjai tegyenek meg mindent a közösség érdekeiről való tudomásszerzés, a társadalom igényeinek megismerése érdekében."13

Büntetőjog-filozófiai szempontból tehát az egyes büntetőjogi törvényi tényállások a mai jogtudományban is feloszthatók aszerint, hogy a büntetőjogi tilalom miként érvényesül. Az úgynevezett adminisztratív jellegű büncselekmények (mala prohibita) nélkülözik az erkölcsi háttérnormát. E cselekményeknél a kriminalizáció indoka, hogy állami kényszerrel érvényesíthető legyen valamely ágazati (közigazgatási norma). Ezzel szemben az önmagában vett rossz cselekedet - vagy ahogy az angolszász jogban illetik, malum in se a cselekmény negatív töltetét valamely közösségi, erkölcsi, elemi szabály megsértéséhez kapcsolja. $^{14}$

Sajátos erkölcs- és értékvédelmi funkciót lát el a büntetőjog az úgynevezett szimbolikus jogalkotás jelenségén keresztül, amelybe azok a jogszabályok, jogi rendelkezések tartoznak, amelyek tényleges regulatív funkcióval nem rendelkeznek, hanem valamely érték elvont, absztrakt védelmét szolgálják. ${ }^{15}$ A büntetőjogi jogalkotásban a szimbolikus elem a Ramsay által megfogalmazott másodlagos funkcióban érhető tetten, azaz amikor a büntetőjogi szabályozás a regulatív funkciót meghaladóan értékvédelmi jelentéstartalmat közvetít. Magyarországon az utóbbi évek gyakorlati kriminálpolitikájának fő jellemzője a (szimbolikus) büntetőjog expanziójában, a punitivitás reneszánszában foglalható össze. ${ }^{16}$ Rixer kiemeli, hogy a szimbolikus jogalkotás célja, hogy egyes átmeneti időszakokban az új alapelveket és eszméket megjelenítse a jogi dokumentumokban annak érdekében, hogy fokozatosan alakítsa át a jogrendszert. Egyes értéktelítettebb alapelvek beépítése ugyanis hosszabb folyamat eredményeként lehetséges csak. ${ }^{17}$

Az erkölcssértő cselekmények büntetendővé nyilvánítása a szabálysértési jogban is megjelenik. A szabálysértésekről szóló 2012. évi II. törvény (Szabstv.) 192. \$-a egy meglehetősen általános tilalmat fogalmaz meg a Közerkölcs megsértése törvényi tényállásában. Eszerint: Aki a közterületen, nyilvános helyen vagy közforgalmú közlekedési eszközön a közerkölcsbe ütköző magatartást tanúsít, szabálysértést követ el. ${ }^{18}$ A törvényi tényállás érdekessége, hogy - Gellér és Ambrus megfogalmazásával élve - quasi nyitott törvényi tényállás, amely elkövethető akár tevéssel, akár mulasztással, viszont - eltérően a (valódi) nyitott törvényi tényállásos bűncselekményektől - nem eredmény-bűncselekmények. ${ }^{19}$

13 Viski László: A szándékos bűnösség és a közösségi motiváció fogalma. Jogtudományi Közlöny, 11. (1956), 9. 512-524. 521.

14 A „malum prohibitum” (statutory wrongdoing) és a „malum in se” (wrong in themselves) fogalmakra lásd részletesen: Fletcher (1998) i. m. 77.

15 Szilágyi Péter: Jogalkotás, törvényhozás, kódex. In Kodifikáció - Szakmai tájékoztató az ELTE Állam-és Jogtudományi Kar VII. Budapesti Nyári Egyetemének hallgatói számára. Budapest, ELTE ÁJK, 2002. 6.

16 Nagy (2013) i. m. 167-168.

17 Rixer a konkrét ellenségkép megjelenítését is a szimbolikus jogalkotás egyik megjelenési formájának tekinti. Vö. Rixer Ádám: Az újabb jogalkotás jellegzetességei. Kodifikáció, (2012), 2. 37-54. 42.

18 Szabstv. 192. $\$(1)$ bek.

19 Gellér Balázs - Ambrus István: A magyar büntetőjog általános tanai. Budapest, ELTE Eötvös Kiadó, 2017. 212. 
Ez a kodifikációs technika alkotmányossági szempontból kifogásolható, tekintve hogy olyan tág megfogalmazásokhoz és önkényes értelmezéshez vezethet, amely a jogbiztonsági klauzulának ellentmond.

\section{A KBTK. KÖZERKÖLCSI KIHÁGÁSAI}

A Kbtk. rendszerében ugyancsak megjelent a közerkölcs védelme. Kodifikációs technikáját illetően a Kbtk.-ban az egyes konkrét erkölcsi elvárások külön-külön tényállásban, nyílt üzenetként közvetítették, hogy pontosan mely etikai zsinórmértéket várja el a jogalkotó. A kódex VII. fejezete „A közrend és közszemérem elleni kihágások” fejezetcím alatt tárgyalta azokat a törvényi tényállásokat, amelyekben a „közszemérem” jogi tárgyának egyes vonatkozásai jelennek meg. A 74-80. \$-okban egyértelmüen a közrend elleni, ezen belül hatósági rendelkezések megtartásával kapcsolatos, többnyire mulasztásos kihágások szerepelnek, amelyek témánk tekintetében figyelmen kívül maradnak, mert kívül esnek a közerkölcsi kriminalizáció körén. A Kbtk. 81. §-ában szereplő kihágás azonban már kétarcú e tekintetben, ugyanis a kéjnőkre vonatkozó hatósági szabályok megszegésére vonatkozik, amely kerettényállást tartalommal kitöltő rendelkezések közerkölcsi, közszeméremre vonatkozó rendelkezéseket is tartalmaztak. ${ }^{20} \mathrm{~A}$ Kbtk. 82-86. \$-ai azonban már egyértelműen közszeméremre vonatkozó (azaz közerkölcsi) büntetőjogi tényállásokat fogalmaztak meg, amelyek között helyet kaptak a fedetlen testtel való megjelenést tilalmazó rendelkezések, ${ }^{21}$ csakúgy, mint a mai rendbontáshoz és garázdasághoz hasonló tényállások, ${ }^{22}$ valamint az állatkínzás tilalmára vonatkozó rendelkezések..$^{23}$

Ezenfelül a Kbtk. tartalmazott olyan immanens közerkölcsöt sértő cselekményi tényállásokat, amelyek expressis verbis ugyan nem tartalmazták a közszemérem vagy közerkölcs kifejezéseket, mégis valamely etikai vagy társadalmi együttélési norma megsértését szankcionálták. Hatásukat tekintve a közerkölcsöt sértő magatartások kriminalizációjáról van szó e tényállások esetén is.

20 „Kéjnők, a kik a reájuk vonatkozó hatósági szabályokat meg nem tartják: egy hónapig terjedhető elzárással büntettetnek” (Kbtk. 81. \$).

${ }^{21}$ „82. \$ A ki a gyógy- vagy szülészintézetek, úgyszintén a fürdők felállitására és kezelésére nézve, a közszemérem szempontjából kiadott szabályokat megszegi: háromszáz forintig terjedhető pénzbüntetéssel büntettetik. 83. $\$$ A ki a közönség szemléletének kitett helyen, szemérmet sértő módon, öltözet nélkül fürdik: nyolcz napig terjedhető elzárással büntetendő."

22 84. \$ A ki nyilvános helyen botrányt okozó részeg állapotban jelen meg: huszonöt forintig terjedhető pénzbüntetéssel büntetendö.

85. $\$$ A ki mást korcsmában, vendéglőben, utczán vagy más nyilvános helyen szándékosan lerészegit, továbbá a kik szeszes italok eladásával iparszerüleg foglalkoznak, és ezek megbizottjai, ha részegnek - noha ezen állapotát tudják - még szeszes italt adnak, ötven forintig terjedhető pénzbüntetéssel büntetendők."

23 „86. $\$$ A ki nyilvánosan, botrányt okozó módon állatot kínoz, vagy durván bántalmaz, úgyszintén, ki az állatkínzás ellen kiadott rendeletet vagy szabályrendeletet megszegi: nyolcz napig terjedhető elzárással és száz forintig terjedhető pénzbüntetéssel büntetendő." 
Idesorolom a Kbtk. 45. \$-ában foglalt hatóságok és közcsend elleni kihágást, amely ténylegesen az egyének társadalmi állásának szokványos rendjét sérti. Megszövegezése szerint: „A ki őt jogosan meg nem illető olyan czimet vagy rangfokozatot használ, a mely által a közönség tévútra vezettetik, valamint az is, a ki őt jogosan meg nem illető belföldi rendvagy díszjeleket, vagy engedély nélkül külföldi rend- vagy díszjeleket nyilvánosan visel: száz forintig terjedhető pénzbüntetéssel büntetendő."

Ugyancsak a társadalmi minimumelvárásokat (közerkölcsöt) sértő cselekmények a valláserkölcsi vonatkozású kihágások, mint például a Kbtk. 51. §-ában foglalt „közbotrányt okozó” vallási tisztelet tárgyára elkövetett gyalázkodási tényállás. ${ }^{24}$

Különösen rejtett módon - keretdiszpozícióba ágyazva - jelenik meg a Kbtk.-ban a vallási alapú társadalmi szokások megsértésére vonatkozó tényállás. Eszerint: „A ki az 1868:LIII. tc. $19 \$$-ának az ünnep- és vasárnapokra vonatkozó intézkedését megszegi: száz forintig terjedhető pénzbüntetéssel büntetendő.” ${ }^{25}$ A tényállást a hivatkozott ágazati norma tölti ki tartalommal, amelynek 19. \$-a úgy rendelkezik, hogy „egyik vallásfelekezetnek tagjai sem kötelezhetők arra, hogy más vallásfelekezetbeliek egyházi szertartásait és ünnepeit megtartsák, vagy hogy ezen napokon bárminemü munkától is tartózkodjanak. Vasárnapokon azonban minden nyilvános és nem elkerülhetlenül szükséges munka felfüggesztendő. Ugyszintén bármely vallásfelekezetnek ünnepén a templom közelében, s egyházi menetek alkalmával azon téreken és utczákon, melyeken az ily menet keresztül vonul, mindaz mellőzendő.” A tényállás nyilvánvalóan a vallásszabadságon túlmenően az egyes felekezetek szokásainak megtartását hivatott biztosítani, amely pedig túlmutat a vallási kérdéseken.

Sajátos kérdés az életvitelszerü utcán tartózkodás, illetve a léha életmód büntetendősége, amely büntetőpolitikai szempontból kizárólag közerkölcsi alapú jogkorlátozásként értelmezhető, tudniillik nincs más olyan kriminalizációs indok vagy más alkotmányos jog, amelynek védelme érdekében a csavargás és koldulás tényállását büntetendővé lehet nyilvánítani. A Kbtk. három tényállást is szentelt az ilyen típusú cselekményeknek. A 62. \$-ban a csavargás tényállását rögzíti, amelynek lényege szerint „akinek bizonyos lakhelye nincs, vagy azt elhagyja és foglalkozás vagy munka nélkül csavarog, ha a hatóság által kitüzött határidő alatt sem a fentartására szolgáló eszközöket, sem azt, hogy azok tisztességes megszerzésére törekszik, kimutatni nem képes, mint csavargó, nyolcz napig terjedhető elzárással büntetendő". A 66 . $\$$ a koldulást szabályozta kihágásként. ${ }^{26}$

Sajátos tiszta mulasztásos törvényi tényállást fogalmazott meg a 64 . $\$$-ban a Kbtk. azzal, hogy a szülők, gyámok, gondnokok és felügyelők a házi fegyelmi jog alkalmazásának elmulasztása miatt felelnek, amennyiben a gyermek a csavargás törvényi tényállását

24 „A ki az állam által elismert valamely hitfelekezet vallásos tiszteleténektárgyát, a vallásos szertartásra rendelt helyiségen kivül és nem a vallásosszertartás alkalmával nyilvánosan meggyalázza és ez által közbotrányt okoz: nyolcz napig terjedhető elzárással büntetendő.”

25 Kbtk. 52. \$.

26 „A ki hatósági engedély nélkül nyilvános helyen, vagy házról-házra koldul, vagy a ki tizenhat éven alóli gyermekeket a koldulásra biztat, vagy koldulni küld, vagy e czélból másnak rendelkezésére bocsát: nyolcz napig terjedhető elzárással büntetendő” (Kbtk. 66. §). 
valósítja meg. Ez a büntetőjogi felelősséget kiterjesztő kodifikációs technika a mai Btk.-ban sem ismeretlen, miszerint valamely kriminális cselekményhez többletfelelősséget társít a jogalkotó azzal, hogy nem magát a bűncselekményt, hanem annak rizikóját, illetve azt a mulasztást bünteti, amely a büncselekmény megvalósulását megakadályozhatta volna.

\section{KONKLÚZIÓ GYANÁNT}

Az erkölcsi alapú kriminalizáció azt a célt szolgálja, hogy a társadalmi alapokat képező közerkölcsi és közrendi normák adott életviszonyhoz igazításával az adott társadalom folyamatos fennmaradása biztosított legyen. A Csemegi-éra kihágásokról szóló büntető törvénykönyve nem nélkülözte a társadalmi minimumelvárások büntetőjogba integrálását. Érdekessége, hogy a mai kiforrott alkotmányjogi és nemzetközi emberi jogi háttér nélkül is képes volt a szükségesség-arányosság józan mércéjét megtartva olyan törvényi tényállásokat alkotni, amelyek a lényegi erkölcsi elvárásokat normativizálták, és nem hatoltak indokolatlanul a privát cselekvési szabadság terrénumába.

Különösen fontosnak tartom, hogy a Kbtk. a mai szabálysértési törvényben megfogalmazott kvázi nyitott törvényi tényálláshoz (közerkölcs megsértése) képest pontosan kifejezett és jól körülhatárolható cselekményeket tartalmazott. Míg a közerkölcs megsértésének mai szabálysértése a túlkriminalizáció jelenségébe illeszthető, és nehezen állja ki a pontos meghatározottság büntetőjogi tényállásokkal szemben támasztott alkotmányos követelményét, addig a Kbtk. közerkölcsi vonatkozású törvényi tényállásai egyértelmű üzenetet hordoznak. E tényállások tehát nem lépik túl a jog-, illetve erkölcsvédelemhez szükséges indokolt határokat. Megjegyzendő, hogy a tényállásokban foglalt szankciók sem túlzók, azaz arányossági problémát sem vetnek fel.

Következtetésem szerint a közerkölcsi kriminalizáció Kbtk.-ban megjelenő történelmi elóképei a társadalmi morálból táplálkozó, a polgári Magyarország mindennapjaiba organikusan illeszkedő tényállások voltak és megfelelő mintául szolgálhatnak azon mai kriminális szabálysértések kodifikációjához, amelyek ténylegesen vagy immanensen a közerkölcs védelmét célozzák. 


\section{FELHASZNÁLT IRODALOM}

1. Devlin, Patrick: The Enforcement of Morals. Oxford, Oxford University Press, 1965.

2. Feinberg, Joel: The Moral Limits of the Criminal Law IV. Harmless Wrongdoing. Oxford - New York, Oxford University Press, 1990. DOI: https://doi. org/10.1093/0195064704.001.0001

3. Fletcher, George P.: Basic Concepts of Criminal Law. Oxford - New York, Oxford University Press, 1998.

4. Gellér Balázs - Ambrus István: A magyar büntetöjog általános tanai. Budapest, ELTE Eötvös Kiadó, 2017.

5. Hamza Gábor - Földi András: A római jog története és institúciói. Budapest, Nemzeti Tankönyvkiadó, 1996.

6. Hart, H. L. A.: Jog, szabadság, erkölcs. Budapest, Osiris, 1999.

7. Molnár Imre: Az ókori római büncselekmény-fogalom ismérvei. Acta Universitatis Szegediensis. Acta Juridica et Politica, (2010), 73. 565-590.

8. Nagy Ferenc: Régi és új tendenciák a büntetöjogban és a büntetö-jogtudományban. Budapest, Akadémiai Kiadó, 2013.

9. Németh Imre: Gondolatok az erkölcsi alapú kriminalizációról. Közjogi Szemle, 4. (2011), 3. 28-37.

10. Pokol Béla: Büntetőjogelméleti vizsgálódások. Budapest, Rejtjel, 2016.

11. Rixer Ádám: Az újabb jogalkotás jellegzetességei. Kodifikáció, (2012), 2. 37-54.

12. Szilágyi Péter: Jogalkotás, törvényhozás, kódex. In Kodifikáció - Szakmai tájékoztató az ELTE Állam-és Jogtudományi Kar VII. Budapesti Nyári Egyetemének hallgatói számára. Budapest, ELTE ÁJK, 2002. Elérhető: www.ajk.elte.hu/file/Kodifikacio_ SzilagyiPeter.pdf (A letöltés dátuma: 2020. 12. 12.)

13. Viski László: A szándékos bűnösség és a közösségi motiváció fogalma. Jogtudományi Közlöny, (1956), 9. 512-524.

Jogi források

1. 1879. évi XL. törvénycikk a magyar büntetö törvénykönyv a kihágásokról

2. 2012. évi II. törvény a szabálysértésekről 
Dr. Németh Imre LL.M., PhD egyetemi adjunktus az Eötvös Loránd Tudományegyetem Állam- és Jogtudományi Kar Büntetőjogi Tanszékének munkatársa. Egyetemi tanulmányait 2000-ben fejezte be az ELTE ÁJK-SzIF Oktatási Intézményben. Ezt követően a Széchenyi István Egyetem Deák Ferenc Állam- és Jogtudományi Karán tevékenykedett 2019-ig, ahol legmagasabb beosztása szerint egyetemi docensként dolgozott. A szerző 2004-ben nemzetközi LL.M. fokozatot szerzett a Helsinki Egyetem Jogi Karán, ahol részt vett az Utrechti Egyetem jogi karával közös csereprogramban is. PhD-fokozatát 2012-ben a Széchenyi István Egyetem Állam- és Jogtudományi Karán szerezte. Kutatási témái: a sértetti beleegyezés büntetőjogi megítélése, az egészségügyi önrendelkezési jog büntetőjogi vetületei, a büntetőjog paradigmaváltása. 